\title{
Precision Nutrient Management in Wheat using Nutrient Expert
}

\author{
Mukesh Kumar* and Bhagat Singh \\ Department of Agronomy, CCS Haryana Agricultural University, \\ Hisar, Haryana, 125004, India \\ *Corresponding author
}

\section{Keywords \\ Wheat, Nutrient Expert, RDF and grain yield}

\section{Article Info}

Accepted:

18 January 2019

Available Online:

10 February 2019

\section{A B S T R A C T}

Nutrient management has played a main role in achieving self-sufficiency in food grain production. A field experiment was conducted during Rabi 2016-17 and 2017-18 to evaluate nutrient requirement of wheat using Nutrient Expert Model (NE is a simple computer based decision support system or delivery tool developed by IPNI [International Plant Nutrition Institute] that can rapidly provide nutrient recommendations for N, P and K for crops). The experiment was conducted in Randomized Block Design replicated thrice at Wheat and Barley Research area, CCS HAU, Hisar, Haryana. Seven treatments executed were absolute control (without NPK), Recommended dose of fertilizer (RDF; $150 \mathrm{~kg} \mathrm{~N} / \mathrm{ha}, 60 \mathrm{~kg} \mathrm{P}_{2} \mathrm{O}_{5} / \mathrm{ha}$ and $40 \mathrm{~kg} \mathrm{~K} \mathrm{~K}_{2} \mathrm{O} / \mathrm{ha}$ ), $150 \% \mathrm{RDF}, 150 \% \mathrm{PK}, 150 \% \mathrm{NK}, 150 \%$ NP and compared with NE (Nutrient Expert Recommendation).Based on pooled two years data 2016-17 and 2017-18, experiment revealed that the highest grain yield (61.27 q/ha) was recorded when $150 \%$ recommended dose of fertiliser was applied which was significantly higher than other treatments except when fertiliser was applied on the basis of nutrient expert model (58.80 q/ha). Similarly, the maximum biological yield (146.22 q/ha) was obtained from 150\% RDF followed by NE (145.67 q/ha). Minimum grain and biological yield was recorded from absolute control treatment which was without fertilizer application. Maximum number of effective tillers $/ \mathrm{m}^{2}$ (428) and plant height $(101.4 \mathrm{~cm})$ were also recorded when $150 \%$ recommended dose of fertiliser was applied. Boldest grain was produced by control (no fertilizer; $41.06 \mathrm{~g}$ ) treatment. Maximum number of grains per ear head (38.89) was recorded from 150\% NK treatment. Lowest grain yield (41.06 q/ha) was recorded from control (no fertilizer) followed by application of $150 \%$ recommended dose of phosphorus and potash without nitrogen. Nutrient Expert based practices produced higher productivity in comparison to recommended dose of fertilizer. Nutrient expert significantly reduced $\mathrm{N}$ fertilizer input while maintain higher yield when compared with $150 \%$ RDF. The application of fertilizers on the basis of recommendation of decision support system "Nutrient expert" proved satisfactory.

\section{Introduction}

Wheat is the second most important cereal crop next to rice in Asia. Wheat is grown on about $29.72 \mathrm{mha}$ in India with production of 98.61mt in 2017-18 and an average yield of $3318 \mathrm{~kg} / \mathrm{ha}$ (ICAR-IIWBR, 2018). There are considerable yield gaps between the major wheat-growing states in the country with highest yield recorded in Punjab (5032 kg/ha) 
and lowest in Chhattisgarh $(933 \mathrm{~kg} / \mathrm{ha})$. The need for precise management of $\mathrm{N}$ fertilizer in wheat for both economic and environmental prospective. Static fertilizer recommendations based on average response lead to excessive and inadequate fertilizers with high $\mathrm{N}$ losses. Inappropriate nutrient management is one of the major factors causing such yields gap (Majumdar et al., 2013). In addition, considerable yield gaps exist (Ladha et al., 2003) between researcher-managed optimum NPK plots and farmers' fertilizer practices, indicating an opportunity for increasing wheat productivity through improved nutrient management practices.

Plant nutrient plays very important role in the production of the crop as well as for the environment. Asian agriculture is characterized by small land holdings for cultivation with high variability in plant nutrient availability between different fields. Site specific nutrient management (SSNM), integrates information from different scales to make field specific decisions on $\mathrm{N} \mathrm{P}$ management. SSNM is a set of nutrient management principles that aims to supply a crop's nutrient requirements tailored to a specific field and for a location specific environment. Its purpose is to account for indigenous nutrient sources, including crop residues and manures; and apply fertilizer at optimal rates and at critical growth stages to meet the deficit between the nutrient needs of a high-yielding crop and the indigenous nutrient supply.

Nutrient Expert (NE) for Wheat is a new nutrient decision support system tool, based on the principles of SSNM and recommends balanced application of nutrients based on crop need. NE is based on the principles of SSNM developed for rice (Dobermann and Witt, 2004) and later adapted in maize and wheat. The tool was a joint development of wheat stakeholders in India including representatives from national research and extension system, private industries, International Maize and Wheat Improvement Centre (CIMMYT), and International Plant Nutrition Institute (IPNI). It enables crop advisers to rapidly develop field-specific nutrient recommendations for wheat using existing site information. A user-friendly nutrient decision support tool that enables researchers, extension specialist and industry agronomists to quickly develop field specific fertilizer recommendations for wheat. Nutrient Expert considers the most important factors affecting nutrient management recommendations in a particular field and enables crop advisers to provide fertilizer guidelines that are suited to their farming conditions. The tool uses a systematic approach of capturing site specific information that is important for developing a location-specific recommendation. Nutrient Expert does not require a lot of data nor very detailed information as in the case of many sophisticated nutrient decision support tools and models, which could overwhelm the user. It allows users to draw the required information from their own experience, the farmers' knowledge of the local region, and the farmers' practices. Nutrient Expert can use experimental field data, but it can also estimate the required SSNM parameters using existing location information.

\section{Materials and Methods}

A field experiment was carried out during the Rabi season of 2016-17 and 2017-18 at Research Farm, Wheat \& Barley Section, Department of Genetics \& Plant breeding, CCS HAU, Hisar, Haryana (India) situated at $29^{\circ} 10^{\prime} \mathrm{N}$ latitude and $75^{\circ} 46^{\prime} \mathrm{E}$ longitude at an elevation of $215.2 \mathrm{~m}$ above mean sea level. The soil of experimental site was sandy loam in texture, having a $\mathrm{pH}$ 7.9, electrical conductivity $0.27 \mathrm{dS} / \mathrm{m}$, low organic carbon 0.27 per cent, available low N $126 \mathrm{~kg} / \mathrm{ha}$, 
available medium $\mathrm{P} 12.3 \mathrm{~kg} / \mathrm{ha}$ and $\mathrm{K} 328$ $\mathrm{kg} / \mathrm{ha}$. The experiment was laid out in Randomised Block Design with seven treatments replicated thrice. Seven treatments was absolute control (without NPK), Recommended dose of fertilizer $(150 \mathrm{~kg}$ $\mathrm{N} / \mathrm{ha}, 60 \mathrm{~kg} \mathrm{P}_{2} \mathrm{O}_{5} / \mathrm{ha}$ and $40 \mathrm{~kg} \mathrm{~K} \mathrm{O} / \mathrm{ha}$ ), $150 \%$ RDF, $150 \%$ PK, $150 \%$ NK, $150 \%$ NP and compared with NE (Nutrient Expert Recommendation). The basal fertilizers in all the treatments including all the $\mathrm{P}$ and $\mathrm{K}$ fertilizers and $1 / 3 \mathrm{~N}$ fertilizer were applied before wheat sowing, remaining the $2 / 3$ dose of $\mathrm{N}$ fertilizer was applied as top-dressed in two splits, $1 / 3$ at the time of first irrigation and $1 / 3^{\text {rd }}$ at second irrigation as per different treatments. Nutrient expert recommendation dose for wheat was $200 \mathrm{~kg} \mathrm{~N} / \mathrm{ha}, 71 \mathrm{~kg}$ $\mathrm{P}_{2} \mathrm{O}_{5} / \mathrm{ha}$ and $75 \mathrm{~kg} \mathrm{~K} 2 \mathrm{O} / \mathrm{ha}$. To carry out the experiment the land preparation operation viz. pre sowing irrigation, plowing and levelling were done. Wheat variety, WH 1105 was sown at a row spacing of $20 \mathrm{~cm}$ manually on $14^{\text {th }}$ November, 2016 during first year and on $10^{\text {th }}$ November, 2017 during second year. Other management practices including irrigation, weeding and hoeing was adopted as per package and practices of wheat crop. Yield attributing parameters were recorded at the time of harvest. Five plants were selected randomly from each treatment to record the observations of yield attributing characters. The crop was harvested on $10^{\text {th }}$ April, 2017 and $17^{\text {th }}$ April, 2018 during first and second year, respectively. The data were analysed using appropriate analysis of variance (ANOVA). OPSTAT software was used to carry out statistical analysis.

\section{Results and Discussion}

\section{Growth studies}

\section{Plant height}

Pooled means of two year data 2016-17 and 2017-18 revealed that the plant height was significantly higher $(101.4 \mathrm{~cm})$ in $\mathrm{T}_{3}(150 \%$ RDF) treatment over control, RDF and $150 \%$ PK treatment but statistically at par with $150 \%$ NK, $150 \%$ NP and nutrient expert treatment (Table 1). Minimum plant height was recorded in absolutely control treatment. The plant height was maximum in 150\% RDF treatment because of higher levels of NPK fertilisers, which provide NPK levels in adequate proportion resulted in increased crop growth. It may be due to the fact that NPK are the major nutrients being the important constituents of chlorophyll, nucleotides, nucleic acid, enzymes, protein, phospholipids, osmotic and ionic regulation, which takes part in various metabolic processes of plant, it increase cell size and cell number by converting the carbohydrates into protoplasm. So, NPK applications were able to cause considerable positive in growth. Plant height in control i.e. $0 \mathrm{~kg} \mathrm{~N} / \mathrm{ha}$ was reduced significantly than increased doses of nitrogen might be because of under nourishment of the plant because of low availability of nutrients as no nitrogen was applied in this treatment (Mukesh and Pannu, 2014).

\section{Yield attributes and yield}

Pooled results of experiment during 2016-17 and 2017-18 data (Table 1) pertained that maximum number of effective tillers $/ \mathrm{m}^{2}$ (428) were also recorded when $150 \%$ recommended dose of fertiliser was applied, which was significantly superior than other treatments but statistically at par with nutrient expert treatment (410) and $150 \%$ NK treatment (406). Absolutely control treatment produced significantly lower number of effective tillers than all other nutritional treatments. Boldest grain was recorded from absolute control (no fertilizer; $41.06 \mathrm{~g}$ ) treatment. Grains/ear head was not affected significantly by different nutrient management treatment; however, it was numerically higher (38.89) in $150 \%$ NK treatment. 
Table.1 Effect of nutrient management practices on yield attributes and yield of wheat (pooled data of 2016-17 and 2017-18)

\begin{tabular}{|c|c|c|c|c|c|c|c|}
\hline Treatments & $\begin{array}{c}\text { Plant } \\
\text { height }(\mathbf{c m})\end{array}$ & 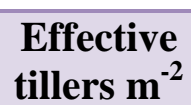 & $\begin{array}{c}\text { Grains } \\
\text { earhead }^{-1}\end{array}$ & $\begin{array}{l}\text { 1000-grain } \\
\text { weight (g) }\end{array}$ & $\begin{array}{c}\text { Grain yield } \\
\left(\mathrm{q} \mathrm{ha}^{-1}\right)\end{array}$ & $\begin{array}{l}\text { Biological } \\
\text { yield }\left(\mathrm{q} \mathrm{ha}^{-1}\right)\end{array}$ & $\begin{array}{c}\text { Harvest } \\
\text { index (\%) }\end{array}$ \\
\hline $\mathbf{T}_{1}$ - Absolute Control & 82.8 & 228 & 35.67 & 41.06 & 32.09 & 85.15 & 37.85 \\
\hline $\mathbf{T}_{2^{-}}-\mathrm{RDF}^{*}$ & 96.5 & 397 & 37.75 & 38.18 & 56.88 & 140.41 & 40.47 \\
\hline$T_{3}-150 \%$ RDF & 101.4 & 428 & 38.60 & 37.28 & 61.27 & 146.22 & 41.97 \\
\hline $\mathbf{T}_{4-}-150 \% \mathrm{PK}$ & 92.7 & 300 & 35.24 & 40.83 & 43.01 & 112.23 & 38.30 \\
\hline$T_{5}-150 \% \mathrm{NK}$ & 100.0 & 395 & 38.89 & 36.51 & 55.47 & 141.15 & 39.30 \\
\hline $\mathrm{T}_{6}-150 \% \mathrm{NP}$ & 100.8 & 406 & 38.38 & 35.50 & 54.66 & 139.45 & 39.21 \\
\hline$T_{7}-$ Nutrient expert $* *$ & 100.3 & 410 & 37.63 & 38.30 & 58.80 & 145.67 & 40.39 \\
\hline LSD $(P=0.05)$ & 2.55 & 24.61 & NS & 2.01 & 4.12 & 8.69 & 0.97 \\
\hline $\mathrm{SE}(\mathbf{m}) \pm$ & 0.82 & 7.90 & 1.14 & 0.65 & 1.32 & 2.79 & 0.31 \\
\hline
\end{tabular}

*Recommended dose of fertiliser (RDF: $150 \mathrm{~kg} \mathrm{~N} / \mathrm{ha}, 60 \mathrm{~kg} \mathrm{P}_{2} \mathrm{O}_{5} / \mathrm{ha}$ and $40 \mathrm{~kg} \mathrm{~K} 2 \mathrm{O} / \mathrm{ha}$ )

**Nutrient expert- $200 \mathrm{~kg} \mathrm{~N} / \mathrm{ha}, 71 \mathrm{~kg} \mathrm{P_{2 }} \mathrm{O}_{5} / \mathrm{ha}$ and $75 \mathrm{~kg} \mathrm{~K}_{2} \mathrm{O} / \mathrm{ha}$

Based on pooled two years data 2016-17 and 2017-18, experiment revealed that the highest grain yield $(61.27 \mathrm{q} / \mathrm{ha})$ was recorded when $150 \%$ recommended dose of fertiliser was applied which was significantly higher than other treatments except when fertiliser was applied on the basis of nutrient expert model $(58.80 \mathrm{q} / \mathrm{ha})$. Similarly, the maximum biological yield (146.22 q/ha) was obtained from $150 \%$ RDF followed by NE (145.67 $\mathrm{q} / \mathrm{ha}$ ). Minimum grain and biological yield was recorded from absolute control treatment which was without fertilizer application. Nutrient expert treatment produced 45.4, 3.3, 26.9, 5.7 and $7.0 \%$ higher grain yield than absolutely control, RDF, $150 \%$ PK, $150 \%$ NK and $150 \% \mathrm{NP}$ treatment. High nitrogen availability plays vital role in cell division or high no. of effective tiller $/ \mathrm{m}^{2}$ (Shrestha et al., 2016).Number of tillers per $/ \mathrm{m}^{2}$, plant height, 1000-grain weight and grain yield were significantly increased by increasing the nitrogen levels over control (Ali et al., 2011). The increase in grain and straw yield with increased doses of fertilisers might be due to improvement in growth, yield attributed characters and higher photosynthetic activity (Kumar et al., 2017).Nitrogen application displayed significant effect on plant height, total dry matter production, test weight and grain yield. Plant height, grains number per ear head, biological yield and grain yield were increased with increasing $\mathrm{N}$ level (Soleimanzadeh et al., 2013). Plant height, number of tillers $\mathrm{m}^{-2}$, 1000-grain weight, grain yield, biological yield and harvest index were highest at higher level of nitrogen (Iqbal et al., 2012). Increasing nitrogen fertilizer rates resulted in significant increase in plant height, number of grain/spike, number of spikes $/ \mathrm{m}^{2}, 1000$ grain weight, grain yield and biological yield. Nutrient Expert based practices produced higher productivity in comparison with recommended dose of fertilizer. Nutrient expert significantly reduced $\mathrm{N}$ fertilizer input while maintain higher yield when compared with 150\% RDF.

Based on two years 2016-17 and 2017-18 data experiment concluded that the highest grain yield $(61.27 \mathrm{q} / \mathrm{ha})$ was recorded when $150 \%$ recommended dose of fertiliser was applied which was significantly higher than other treatments except when fertiliser was applied on the basis of nutrient expert model (58.80 $\mathrm{q} / \mathrm{ha}$ ). Nutrient Expert based practices produced higher productivity in comparison to recommended dose of fertilizer. Nutrient 
expert significantly reduced $\mathrm{N}$ fertilizer input while maintain higher yield when compared with $150 \%$ RDF. Experiment indicates that production can be increased with the use of nutrient expert in Wheat.

\section{References}

Dobermann, A. and Witt, C. 2004. In: A. Dobermann, C. Witt, D. Dawe. (Eds.), Increasing productivity of intensive rice systems through site-specific nutrient management. Enfield, NH (USA) and Los Baños (Philippines): Science Publishers, Inc., and International Rice Research Institute (IRRI), pp. 75-100.

Ali, A., Ahmad, A., Syed, W.H., Khaliq, T., Asif, M., Aziz, M. and Mubeen M .2011. Effects of nitrogen on growth and yield components of wheat. Science International (Lahore).23 (4): 331-332.

ICAR-IIWBR. 2018. Director's report of AICRP on Wheat and Barley.2017-18, Ed: G.P. Singh. ICAR-Indian Institute of Wheat and barley Research, Karnal, Haryana, India. Pp. 94.

Kumar, M., Pannu, R.K. and Singh, B. 2017. Response of irrigation frequencies and nitrogen doses on yield and yield attributes of late sown wheat. Annals of Biology.33 (1): 69-73.

Ladha, J.K., Dawe, D., Pathak, H., Padre, A.T., Yadav, R.L., Singh, B., Singh,
Y., Singh, P., Kundu, A.L., Sakal, R., Ram, N., Ragmi, A.P., Gami, S.K., Bandari, A.L., Amin, R., Yadav, C.R., Battarai, E.M., Das, S., Aggarwal, H.P., Gupta, R.K. and Hobbs, P.R. 2003. How extensive are yield declines in long-term rice-wheat experiments in Asia? Field Crops Research. 81: 159-180.

Majumdar, K., Jat, M.L., Pampolino, M., Dutta, S. and Kumar, A. 2013. Nutrient management in wheat: current scenario, improved strategies and future research needs in India. Journal of Wheat Research. 4: 1-10.

Mukesh and Pannu, R.K. 2014. Effect of irrigation and nitrogen levels on growth and yield of late sown wheat. Haryana Journal of Agronomy. 30 (2): 119-124.

Shrestha A, Gupta G. and Subedi R. 2016. Evaluation of improved nutrient management practice in yield of rice in Jhapa District. International Journal of Research in Applied Natural and Social Sciences. 4(3): 6774.

Soleimanzadeh, H. and Gooshchi, F. 2013. Effects of azotobacter and nitrogen chemical fertilizer on yield and yield components of wheat (Triticum aestivum L.). World Applied Sciences. 21(8): 1176-1180.

\section{How to cite this article:}

Mukesh Kumar and Bhagat Singh. 2019. Precision Nutrient Management in Wheat using Nutrient Expert. Int.J.Curr.Microbiol.App.Sci. 8(02): 2265-2269.

doi: https://doi.org/10.20546/ijcmas.2019.802.263 